FORAMS 2006

\title{
The impact of orbitally forced upwelling on Oligocene planktic foraminifera $\delta^{13} \mathrm{C}$ and abundances
}

\author{
Bridget S. Wade; William A. Berggren \& Richard K. Olsson \\ Department of Geological Sciences, Wright Geological Laboratory, Rutgers, \\ The State University of New Jersey, 610 Taylor Road, Piscataway, \\ NJ 08854-8066, U.S.A. - bwade@rci.rutgers.edu
}

Planktonic foraminifera from a continuous Oligocene sequence with clear magnetochronology, sediment cycles and abundant foraminifera at Ocean Drilling Program Site 1218 (equatorial Pacific) were sampled in the interval from 27 to $30 \mathrm{Ma}$ at $10 \mathrm{~cm}$ resolution. Taxa of the genus Paragloborotalia are particularly common through the interval studied and we examined the size, relative abundance, stable isotopes and coiling direction of Paragloborotalia taxa.

Multispecies stable isotope data indicate Globoquadrina venezuelana and Dentoglobigerina globularis were probable mixed-layer dwellers, with paragloborotaliids recording heavier $\delta^{18} \mathrm{O}$ signatures consistent with a thermocline habitat. Cyclic variations in the abundances of Paragloborotalia nana matching eccentricity (100 kyr) variations in percent carbonate and $\delta^{13} \mathrm{C}$, suggest orbitally forced upwelling in the equatorial Pacific Ocean and that $P$. nana was a eutrophic species responding directly to changes in surface water productivity. Five chambered forms consistent with Paragloborotalia opima are present throughout the section studied. An abrupt dwarfing (50\% size decrease) in Paragloborotalia nana, P.opima and P. pseudocontinuosa occurs within Chron 9n.

However, this dramatic change in size is not associated with any event recorded in the stable isotope records. The high resolution biostratigraphy has been calibrated to the magnetochronology to constrain the extinction of Paragloborotalia opima (sensu strictu) which marks the top of planktonic foraminifera biozone $\mathrm{O5}$ (P21b). In addition, we find the extinction of Chiloguembelina cubenisis within Chron 10n.1n is consistent with other deep-sea sections 